\title{
EBV Infection Resulting in Aplastic Anemia: A Case Report and Literature Review
}

Israa Khan', Susumu Inoue ${ }^{3 *}$, Rao Mushtaq ${ }^{2}$ and Nkechi Onwuzurike ${ }^{3}$

${ }^{1}$ Departments of Pediatrics, Hurley Children's Hospital/Michigan State University, USA

${ }^{2}$ Departments of Combined Internal Medicine-Pediatrics, Hurley Children's Hospital and Hurley Medical Center/Michigan State University, USA

${ }^{3}$ Department of Pediatric Hematology/Oncology, Hurley Children's Hospital/Michigan State University, USA

\begin{abstract}
We describe a three year old girl who developed aplastic anemia concurrent with reactivation of EBV infection. Literature review yielded a list of 23 cases of documented EBV infection with aplastic anemia. Though acyclovir was used as one of the treatment modality in many cases including ours, its effectiveness is unclear. It would be beneficial to develop EBV associated aplastic anemia registry to prospectively evaluate Acyclovir's effectiveness. Also evaluation for evidence of EBV infection in all cases of idiopathic aplastic anemia would be useful.
\end{abstract}

\section{Keywords: Aplastic anemia; Acyclovir}

\section{Background and Introduction}

Although in a majority of immunologically normal children, EBV infection is a benign illness resulting in no significant complications, some children have been reported to have life-threatening hematological complications. These include Coombs test positive hemolytic anemia, severe thrombocytopenia, agranulocytosis, and aplastic anemia [1]. We have recently cared for a 3 year old child who developed pancytopenia due to bone marrow failure associated with reactivation of EBV infection. Review of the literature showed only twenty-three reported cases with this association (Table 1 and references cited in the table). Severe but transient neutropenia and thrombocytopenia with EBV infection are common [1]. In addition several well documented cases of ITP transitioning into aplastic anemia have been found in the literature $[2,3]$. Thus one needs to be aware that in rare occasions, persistent bone marrow failure may follow what appeared to be transient cytopenia with EBV infection.

\section{Case Description}

A three year-old African American female child presented with complaints of fever, irritability and lethargy for the past 6 days. She had decreased energy associated with fatigue, decreased appetite, respiratory symptoms, and cough. Mother noticed pallor. The child was given ibuprofen which provided temporary relief to fever. She also developed painful oral lesions on buccal mucosa, upper and lower lip and gums two days prior to admission. A painful raised lesion on left hip appeared on the day before admission. She also had diffuse small bruises on her skin. The patient was taken to an urgent care and found to have inflamed tonsils and anemia. She presented to our facility because of these complaints.

She had no significant past medical history. She was not taking any medications except Ibuprofen for fever and had no known allergies. The child's mother was treated for iron deficiency anemia and grandmother had sarcoidosis.

Physical examination revealed a febrile pale and acutely ill-looking girl with clear rhinorrhea. She had hemorrhagic painful blisters on lips and buccal mucosa, pharyngeal erythema with enlarged inflamed tonsils without exudates, and shotty non tender bilateral anterior cervical lymphadenopathy. She was tachycardic, the liver and spleen were not palpable. There was left hip ecchymosis with no restriction in range of motion.
Initial lab results showed WBC: 3.5 (neutrophils 7, lymphocytes 91, mono 1, eosino 1), Hb: $3.3 \mathrm{~g} / \mathrm{dL}$, Hct: $9.4 \%$, platelets: $6 / \mu \mathrm{L}, \mathrm{RBC}$ : 0.96 million/ $\mu \mathrm{L}, \mathrm{MCV}$ : 97.8, Serum ferritin 198 (10-291 ng/ml), Serum iron $85(50-170 \mu \mathrm{g} / \mathrm{dL})$, TIBC 192 (261-478), iron saturation $44 \%$ (21-42\%). Serum folate and B12 were both elevated, $>24$ (5.4-24 ng/ $\mathrm{ml})$, and $>2000(211-911 \mathrm{pg} / \mathrm{mL})$ respectively (Reticulocytes $0.01 / \mu \mathrm{L}$ ). Peripheral smear showed macrocytosis, markedly decreased WBC with many mature lymphocytes, no blast, and no platelets. Chest X-ray was normal and showed no mediastinal mass. The bone marrow biopsy and aspiration showed $15 \%$ cellularity. The predominant cellular elements were mature lymphocytes. There were plasma cells, but mast cells were not increased. Fetal Hemoglobin was 7\%. A PNH (paroxysmal nocturnal hemoglobinuria) test for Pi-Link Ag was normal. A DEB stressed blood chromosome breakage study was normal.

Pertinent viral studies showed: positive EBV VCA IgG and negative IgM. Blood EBV DNA quantitation showed 8,613copies/ml. EBNA IgG titer showed $>750(<18)$, EBV EA IgG titer also showed $>150(<9)$, both of which were extremely high, indicating reactivation of EBV infection. HHV 6 IgG antibodies titer was1:160, but IgM titer was $<1: 20$. Parvo virus B19 DNA by PCR was negative. CMV IgG and IgM antibodies were negative. The patient received IV antibiotics; blood and platelet transfusions, became afebrile and was discharged in clinically stable condition. Subsequently patient did not improve, and had become transfusion dependent, though she remained free from any infections.

Three weeks after diagnosis, EBNA IgG titer was still $>750$. Bone marrow biopsy 1 month later showed identical findings to the first ones. We started her on prednisolone at $2 \mathrm{mg} / \mathrm{kg} /$ day and IV acyclovir daily for 7 days. Following Acyclovir treatment, EBV DNA quantitation showed $<200$ copies/ml of blood (undetectable), but she showed no hematological response. And thus one month later we started a regimen of ATG $40 \mathrm{mg} / \mathrm{kg} /$ day daily x 4 days, prednisolone $2 \mathrm{mg} / \mathrm{kg} /$ day, and cyclosporine $15 \mathrm{mg} / \mathrm{kg} /$ day one month after completion of

*Corresponding author: Susumu Inoue, Departments of Pediatrics and Hematology Oncology, Hurley Children's Hospital, USA, E-mail: Dr.Susumulnoue@hurleymc.com

Received May 24, 2013; Accepted June 04, 2013; Published June 08, 2013

Citation: Khan I, Inoue S, Mushtaq R, Onwuzurike N (2013) EBV Infection Resulting in Aplastic Anemia: A Case Report and Literature Review. J Blood Disorders Transf 4:141. doi:10.4172/2155-9864.1000141

Copyright: (c) 2013 Khan I, et al. This is an open-access article distributed unde the terms of the Creative Commons Attribution License, which permits unrestricted use, distribution, and reproduction in any medium, provided the original author and source are credited. 
Citation: Khan I, Inoue S, Mushtaq R, Onwuzurike N (2013) EBV Infection Resulting in Aplastic Anemia: A Case Report and Literature Review. J Blood Disorders Transf 4:141. doi:10.4172/2155-9864.1000141

Page 2 of 3

\begin{tabular}{|c|c|c|c|c|c|c|c|c|c|}
\hline $\begin{array}{l}\text { Ref } \\
\text { No* }\end{array}$ & $1^{\text {st }}$ author & Journal & Yr & vol-page & age & sex & evidence of EBV inf & treatment & status \\
\hline [9] & Mir and Delamore & Scand J Haematol & 1973 & $11 ; 314-8$ & 20 & $M$ & Paul-Bunnel test & prednisolone & recovered \\
\hline [10] & Van Doornik et al. & Scand J Haematol & 1978 & $20: 52-56$ & 7 & $M$ & $\begin{array}{c}\text { Paul-Bunnel test, anti EBV VCA } \\
\text { EBNAAb }\end{array}$ & supportive & died \\
\hline$[5]$ & Shadduck et al. & Exp Hematol & 1979 & $7 ; 264-71$ & 17 & $\mathrm{~F}$ & $\begin{array}{c}\text { anti-EBV IgG \& IgM, } \\
\text { heterophile }\end{array}$ & prednisone, androgen, ATG & recovered \\
\hline [11] & $\begin{array}{l}\text { Lazarus and } \\
\text { Baehner }\end{array}$ & Pediatr & 1981 & $67 ; 907-910$ & 12 & $\mathrm{~F}$ & $\begin{array}{l}\text { mono spot, "fluorescent } \\
\text { antibody test" }\end{array}$ & prednisone & recovered \\
\hline [12] & Ahronheim et al. & N Engl J Med & 1983 & $309 ; 313-314$ & 12 & $\mathrm{~F}$ & $\begin{array}{l}\text { VCA IgG \& IgM, EBNA, } \\
\text { genome by dot-blot }\end{array}$ & & died \\
\hline [13] & Sullivan & N Engl J Med & 1984 & $311 ; 314-322$ & 3 & M & $\begin{array}{c}\text { VCA IgG \& IgM, neg Suthern } \\
\text { blot }\end{array}$ & supportive & died \\
\hline [14] & Sawka et al. & CMAJ & 1987 & $136 ; 730-1$ & 17 & $\mathrm{~F}$ & monospot, VCA IgG rising & prednisone, Danazol, ATG & recovered \\
\hline [15] & Schimke et al. & $\begin{array}{l}\text { Am J Med } \\
\text { Genetics }\end{array}$ & 1987 & $27: 195-202$ & NA & NA & VCA $\lg G, \lg A$ & NA & died \\
\hline \multirow[t]{6}{*}{ [3] } & Baranski et al. & Ann Int Med & 1988 & $109 ; 695-704$ & 29 & $M$ & $\begin{array}{c}\text { +mono spot, +EBV VCA IgM, } \\
\text { Southern }\end{array}$ & ATG, acyclovir, cyclosporin & died \\
\hline & Baranski et al. & & 1988 & & 25 & $M$ & VCA IgG, IgA, EA, EBNA & acyclovir, ATG, androgen & died \\
\hline & Baranski et al. & & 1988 & & 13 & $M$ & Monospot, VCA IgG, EA, EBNA & Acyclovir, ATG & recovered \\
\hline & Baranski et al. & & 1988 & & 15 & $\mathrm{~F}$ & VCA IgG, EA & $\begin{array}{l}\text { Acyclovir, ATG, cyclosporin, } \\
\text { steroids }\end{array}$ & died \\
\hline & Baranski et al. & & 1988 & & 22 & $M$ & VCA IgG, EA, EBNA & prednisone, ATG & improved \\
\hline & Baranski et al. & & 1988 & & 1.6 & $M$ & VCA IgG, EA, EBNA & $\begin{array}{c}\text { Acyclovir, Oxymethalone, } \\
\text { ATG }\end{array}$ & no imrovement \\
\hline [16] & Grishaber et al. & Am J Hematol & 1988 & $28: 273-275$ & 15 & $\mathrm{~F}$ & $\begin{array}{c}\text { +mono spot, +EBV VCA IgG } \\
\text { \& EBNA }\end{array}$ & prednisone & recovered \\
\hline [2] & Weinblatt & $\begin{array}{l}\text { Am J Pediatr } \\
\text { Hematol Oncol }\end{array}$ & 1991 & $13 ; 465-9$ & 1 & $M$ & VCA IgM & prednison, IVIG, ATG & partial recovery \\
\hline [17] & Inoue et al. & Int Medicine & 1994 & $33 ; 303-7$ & 13 & $\mathrm{~F}$ & $\begin{array}{c}\text { VCA \& EA IgG, EBV DNA by } \\
\text { Southern blot }\end{array}$ & IVIG, G-CSF & died \\
\hline [4] & Lau et al. & $\begin{array}{l}\text { J Paediatr Child } \\
\text { Health }\end{array}$ & 1994 & $30: 74-76$ & 9 & $\mathrm{~F}$ & $\begin{array}{c}\text { rising ab titers in EBV VCA IgG } \\
\text { and EBNA, EBV genome + by } \\
\text { PCR, acyclovir }\end{array}$ & ATG \& Methylprednisolone & recovered \\
\hline [18] & Anderlini et al. & Br J Haematol & 1999 & $106 ; 159-61$ & 17 & $\mathrm{~F}$ & monospot, VCA IgM & $\begin{array}{c}\text { steroids, IVIG, G-CSF, Epo, } \\
\text { syngneic transplant x } 2 \text { after } \\
\text { cytoxan \& ATG }\end{array}$ & recovered \\
\hline [19] & Kaptan et al. & Am J Hematol & 2001 & $67 ; 252-255$ & 22 & M & $\begin{array}{l}\text { VCA IgG \& IgM, EBV \& } \\
\text { HPVB19 DNA + by PCR }\end{array}$ & $\begin{array}{c}\text { prednisone, acyclovir, IVIG, } \\
\text { BMT }\end{array}$ & recovered \\
\hline \multirow[t]{2}{*}{ [20] } & Nijhawan et al. & $\begin{array}{l}\text { J Assoc Physic } \\
\text { India }\end{array}$ & 2005 & $53: 1079$ & 11 & $M$ & EBV IgM (VCA?) & supportive & died \\
\hline & Nijhawan et al. & & 2005 & & 3 & $M$ & VCA IGG, EBNA & dexamethasone, ATG & recovered \\
\hline \multirow[t]{2}{*}{ [21] } & Ergene et al. & Transfus Apher Sci & 2007 & $37 ; 125-9$ & 48 & $\mathrm{~F}$ & VCA IgG \& IgM & G-CSF, supportive & recovered \\
\hline & Inoue S & Khan I & 2013 & & 3 & $\mathbf{F}$ & $\begin{array}{l}\text { VCA IgG, EA, EBNA, EBV } \\
\text { DNA copies }\end{array}$ & $\begin{array}{c}\text { acyclovir, steroids, ATG, } \\
\text { cyclosporin }\end{array}$ & \\
\hline
\end{tabular}

* indicates the number in the reference in the text

Table 1: EBV infection resulting in aplastic anemia.

acyclovir. Cyclosporin was continued following the cessation of ATG. Prednisolone was gradually tapered off.

Approximately 2 months after initial presentation, patient still showed EBNA IgG titers of $694(<18)$, EBV EA IgG $52.2(<9)$ and EBV DNA Quantitation 1216 copies $(<200)$.

After receiving one cycle of ATG/CSA, she had partial response with recovery of $\mathrm{WBCs}$ but remained heavily transfusion dependent for RBCs and platelets. Two months after this therapy, EBV DNA was $<200$ copies, EBV EA IgG titer was 37.3 and EBNA IgG was $>750$. A second cycle of ATG and oral cyclosporine was given six months later.
Investigations for Fanconi anemia, Dyskeratosis congenita, congenital amegakaryocytic thrombocytopenia, and paroxysmal nocturnal hemoglobinuria $(\mathrm{PNH})$ were negative. She is still transfusion dependent.

\section{Discussion}

Aplastic anemia following primary EBV infection or in association with reactivation of EBV infection has been well documented in the literature, but must be rare, since we were able to find only 23 documented cases in the literature. The case described here is development of aplastic anemia apparently following reactivation of EBV infection, but there are 
case reports of aplastic anemia after primary infection. Several patients developed clear cut ITP (with large platelets in blood and many marrow Megakaryocytes), only to develop bone marrow failure later resulting in aplastic anemia [2] (case 5 of Baranski et al.) [3]. Some patients did not have illnesses suggestive of infectious mononucleosis, yet when the patient developed aplastic anemia, there was serological or molecular evidence that patient had recent EBV infection [4], (patients 5 and 6 of Baranski et al.) [3]. These cases suggest that EBV induced aplastic anemia may be much more common than the literature indicates

The current understanding regarding the rationale of immunosuppressive therapy for acquired aplastic anemia is based on experimental and clinical observations that suppressor cells in the patients inhibit autologous marrow hematopoietic cells growth. More than 30 years ago, Shadduck et al. presented in vitro evidence that patient's bone marrow cells inhibited normal myeloid colony growth in vitro. These inhibitor cells disappeared after the patient recovered with ATG treatment [5]. Kurtzman and Young described their observation that activated $\mathrm{T}$ cells by exposure to autologous EBV infected B cells inhibited hematopietic cell growth in colony culture [6]. A recent review on aplastic anemia by Young et al. [7] presented evidence that suppressor cells (effector cells) are CD8 ${ }^{+}, \mathrm{CD} 28^{-}$cells. These cells disappear when patients achieve remission. EBV infection may stimulate oligoclonal expansion of these $\mathrm{T}$ cells in susceptible hosts.

Many patients were treated with Acyclovir (Table 1), but its role in the efficacy of treatment is unclear, since all the patients treated with acyclovir were also treated with other agents. The majority of the patients were treated with steroids and ATG, some with androgens. Thirteen of the 23 patients were documented to have recovered or improved. The remainder either died or their status is unknown. Most patients had severe aplastic anemia by Camitta's criteria [8]. Thus EBV associated aplastic anemia does not appear to be different from idiopathic aplastic anemia regarding the prognosis [9-15].

It is likely that some of the "idiopathic aplastic anemia" is triggered by an EBV infection, particularly because in small children EBV infection does not cause stereotypical symptoms [16-21]. It would be helpful to know if acyclovir is beneficial for the treatment in these cases, but at this moment it is unanswered. It would be useful to develop a registry of cases with aplastic anemia induced by EBV and examine the effect of acyclovir in these patients.

\section{References}

1. Jenson HB (2011) Chapter 246, Epstein-Barr Virus :(Kliegman, Stanton, St Geme et al ed.) Nelson Textbook of Pediatrics. (19thedn). Elsevier-Saunders.

2. Weinblatt ME (1991) Immune thrombocytopenic purpura evolving into aplastic anemia in association with Epstein-Barr virus infection. Am J Pediatr Hematol Oncol 13: 465-469.

3. Baranski B, Armstrong G, Truman JT, Quinnan GV Jr, Straus SE, et al. (1988) Epstein-Barr virus in the bone marrow of patients with aplastic anemia. Ann Intern Med 109: 695-704.

4. Lau YL, Srivastava G, Lee CW, Kwong KY, Yeung CY (1994) Epstein-Barr virus associated aplastic anaemia and hepatitis.J Paediatr Child Health 30: 74-76.

5. Shadduck RK, Winkelstein A, Zeigler Z, Lichter J, Goldstein M, et al. (1979) Aplastic anemia following infectious mononucleosis: possible immune etiology. Exp Hematol 7: 264-271.
6. Kurtzman G, Young N (1989) Viruses and bone marrow failure. Baillieres Clin Haematol 2: 51-67.

7. Young NS, Calado RT, Scheinberg $P$ (2006) Current concepts in the pathophysiology and treatment of aplastic anemia. Blood 108: 2509-2519.

8. Camitta BM, Rappeport JM, Parkman R, Nathan DG (1975) Selection of patients for bone marrow transplantation in severe aplastic anemia. Blood 45: 355-363.

9. Mir MA, Delamore IW (1973) Aplastic anaemia complicating infectious mononucleosis. Scand J Haematol 11: 314-318.

10. van Doornik MC, van 'T Veer-Korthof ET, Wierenga H (1978) Fatal aplastic anaemia complicating infectious mononucleosis. Scand J Haematol 20: 52-56.

11. Lazarus KH, Baehner RL (1981) Aplastic anemia complicating infectious mononucleosis: a case report and review of the literature. Pediatrics 67: 907 910 .

12. Ahronheim GA, Auger F, Joncas JH, Ghibu F, Rivard GE, et al. (1983) Primary infection by Epstein-Barr virus presenting as aplastic anemia. $\mathrm{N}$ Engl $\mathrm{J}$ Med 309: 313-314.

13. Sullivan JL (1984) Case Records of the Massachusetts General Hospital. Case 31-1984 - A Three-Year-Old Boy with Fever, Pancytopenia, and Multisystem Failure. N Eng J Med 311:314-322

14. Sawka CA, Bessette JA, Furie B, Desforges JF (1987) Aplastic anemia complicating infectious mononucleosis. CMAJ 136: 730-731.

15. Schimke RN, Collins D, Cross D (1987) Nasopharyngeal carcinoma, aplastic anemia, and various malignancies in a family: possible role of Epstein-Barr virus. Am J Med Genet 27: 195-202.

16. Grishaber JE, McClain KL, Mahoney DH Jr, Fernbach DJ (1988) Successfu outcome of severe aplastic anemia following Epstein-Barr virus infection. Am J Hematol 28: 273-275.

17. Inoue H, Shinohara K, Nomiyama J, Oeda E (1994) Fatal aplastic anemia caused by Epstein-Barr virus infection after autologous bone marrow transplantation for non-Hodgkin malignant lymphoma. Intern Med 33: 303-307.

18. Anderlini P, Riggs SA, Körbling M, Champlin R (1999) Syngeneic blood stem cell transplantation for infectious mononucleosis-related aplastic anaemia. $\mathrm{Br}$ Haematol 106: 159-161.

19. Kaptan K, Beyan C, Ural AU, Ustün C, Cetin T, et al. (2001) Successfu treatment of severe aplastic anemia associated with human parvovirus B19 and Epstein-Barr virus in a healthy subject with allo-BMT. Am J Hematol 67 252-255.

20. Nijhawan S, Joshi A, Shende A, Malhotra H, Mathur A, et al. (2005) EBVassociated hepatitis with aplastic anemia. J Assoc Physicians India 53: 1079.

21. Ergene U, Ozbalci D, Baykal B, Metin Ciris I, Yariktas M (2007) Aplastic anemia, mucormycosis and aspergillosis in infectious mononucleosis: success is possible. Transfus Apher Sci 37: 125-129. 